\title{
EL DESGARRO-HEINE: ESPIRITUALISMO Y SENSUALISMO COMO TENSIÓN EN TRES RELATOS
}

\author{
Pia Paganelli* \\ Universidad de Buenos Aires
}

\begin{abstract}
Resumen: Abordar la obra de Heine es aproximarse a uno de los escritores más controvertidos, pero también más conscientes de la dimensión histórica de la crisis que caracterizó al período que le tocó vivir. Tensionado entre el Romanticismo y la Era Moderna, su obra es la respuesta estética que apunta hacia lo nuevo, sin dejar por eso de observar críticamente lo que en él puede haber de problemático, y sabiéndose heredero al mismo tiempo, del período cultural anterior, al cual empero atacó de manera sumamente crítica. En este trabajo, se analizarán tres relatos - De las memorias del señor de Schnabelewopski, publicado en 1833, Noches Florentinas de 1835, y El rabino de Bacherach de 1840 - que problematizan la tensión entre espiritualismo y sensualismo, para demostrar que la unidad desgarrada, en términos de antítesis de elementos, constituye la unidad estructural de la obra de Heine. Dado que, la escisión establecida por el judeo-cristianismo entre espiritualismo y sensualismo se prolonga en la literatura del Romanticismo a partir de sus representaciones etéreas, idealizadas y desapegadas del presente; y esto le permite a Heine utilizar esos mismos motivos para criticarlos, y al hacerlo, criticar todo un estado de cosas de su presente histórico. Palabras clave: Literatura Alemana. Romanticismo Alemán. La Joven Alemania. Heinrich Heine. Espiritualidad y Sensualidad.
\end{abstract}

\begin{abstract}
Querido lector, si quieres lamentarte del desgarro, harias bien en lamentarte de que el mundo se haya roto en dos partes. Y porque el corazón del poeta es el centro del mundo, se desgarra de modo lastimero en el momento presente [...] Por el mío corrió el gran desgarro del mundo y por ello sé que los grandes dioses me han favorecido ante muchos otros, estimándome digno del martirio de ser poeta. ${ }^{l}$ Henrich Heine.
\end{abstract}

\section{La unidad desgarrada}

La condición de poeta que representa la figura de Heine es efectivamente aquella del

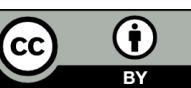

Esta obra está licenciada sob uma Creative Commons - Atribuição 4.0

\footnotetext{
* Doctora en Literatura por la Universidad Nacional de Buenos Aires (Argentina), becaria de posdoctorado de CONICET y profesora en la Cátedra de Literatura brasileña y portuguesa de la Carrera de Letras (UBA). Publicó el libro P(r)o(f)etas del Reino. Literatura y Teología de la liberación en Brasil (Imago Mundi, 2015). E-mail: piapaganelli@gmail.com.

${ }^{1}$ Extraído del artículo: Largo, José Ramón Martín. Los escritores y la música. Filomúsica Revista, n. 37, febrero de 2003.
} 
sujeto desgarrado. La mayoría de los críticos que abordaron su obra ponen en evidencia tal condición. Se trata del desgarro como escisión, contradicción e imposibilidad, y que se refleja en múltiples planos: entre espíritu y materia, ideal y realidad; y también entre el individuo y una sociedad tensionada entre lo viejo (tanto en la dimensión política como en la dimensión estética) que aún persiste, y lo nuevo que no consigue nacer. Un desgarro de carácter cosmopolita y universal que despierta en Heine el proyecto de una nueva concepción estética. Se trata, entonces, de un desgarro "moderno", aquel del individuo sometido y aniquilado en razón de los intereses de la sociedad burguesa.

En el siglo XIX, el desgarramiento del sujeto, el desarrollo frenético de la era industrial, y las sucesivas experiencias revolucionarias fallidas, consolidaron el modelo de la sociedad moderna, de la cual Heine se erige como principal representante y crítico. Es por esto que, tanto para Lukács como para Adorno, Heine es emblema del primer poeta moderno, a causa de las contradicciones en las cuales se vio envuelto a lo largo de su vida, y a causa de aquellas contradicciones reflejadas en términos de disputas estéticas dentro de su propia obra:

\footnotetext{
Heine será, con Balzac, el último gran escritor de talla universal que posea la burguesía de Europa occidental, porque, al igual que aquel, ha encontrado una forma adecuada para el libre movimiento de las contradicciones [...] Crea por lo tanto, una nueva forma, en la que las contradicciones quedan petrificadas como tales contradicciones, del mismo modo que en la forma antigua quedaban petrificadas como armonía [...] En este tipo de poesía revolucionaria Heine es, como él mismo dice, el último poeta romántico y, al mismo tiempo, el primer poeta moderno (LUKÁCS, 1970, p. 139-140).
}

En este sentido, Lukács se refiere a la "condición fronteriza" de Heine entre el período de ascensión de la burguesía y el de su decadencia; ya que a lo largo de su vida, Heine osciló entre una clara conciencia respecto del papel revolucionario del proletariado -lo cual lo situaba en un rol marginal dentro del campo intelectual burgués-, y cierta búsqueda de aceptación o conciliación con el sector de la aristocracia feudal alemana a causa de su imposibilidad por conseguir una independencia material: "Es consciente de la innegable necesidad histórica de la revolución proletaria, y, sin embargo, tiembla a un tiempo ante su posible victoria, pensando que equivaldría a una decadencia de la cultura" (LUKÁCS, 1970, p. 113). Por este motivo, el rol de revolucionario solitario le permitió a Heine desarrollar, a través de su obra, una actitud crítica con respecto al pasado feudal (era ferviente admirador de las conquistas de la Revolución Francesa) y con respecto al presente de Alemania, país que consideraba anacrónico en relación a las conquistas políticas acaecidas en Francia.

Estas contradicciones constituyen la base de las críticas que se le adjudican a la obra y a la personalidad de Heine, críticas que Adorno procura revertir a partir de una relectura de 
Heine como emblemas del poeta moderno: "Heine es el primer poeta alemán "moderno" en tanto es el primero en expresar el conflicto no sólo con el mundo exterior sino con su propia interioridad, el primero que no reflejó meramente aquel conflicto sino que dio evidencias del mismo a través de cada sutileza de su forma” (ADORNO, 2014, p. 346).

En consecuencia, abordar la obra de Heine es aproximarse a uno de los escritores más controvertidos, pero también más conscientes de la dimensión histórica de la crisis que caracterizó al período que le tocó vivir. Tensionado entre lo viejo y lo nuevo, entre el romanticismo y la era moderna, su obra es la respuesta estética que apunta hacia lo nuevo -un futuro en términos de utopía estética-, sin dejar por eso de observar críticamente lo que en él puede haber de problemático, y sabiéndose heredero al mismo tiempo, del período cultural anterior, al cual empero atacó de manera sumamente crítica. Por lo tanto, los relatos de Heine suponen una estructura de difícil coherencia, en la cual la antítesis de elementos constituye la unidad estructural de la obra.

Se trata entonces de una unidad desgarrada, del desgarro-Heine. Desgarro que se analizará en tres relatos - De las memorias del señor de Schnabelewopski, publicado en 1833, Noches Florentinas de 1835, y El rabino de Bacherach de 1840 - que problematizan la tensión entre espiritualismo y sensualismo, no sólo en términos de los contenidos que manejan, sino también en la estructura de contrastes entre espacios y personajes que los delinean.

\section{Una época de crisis: La ruptura de la armonía, la instalación del desgarro}

Heine escribió en el contexto de la Restauración (1815-1848) instaurada por el Congreso de Viena tras la caída de Napoleón con el objetivo de restablecer el estado de cosas anterior a la Revolución Francesa. En Alemania, en donde se habían ido desarrollando aspiraciones de unidad nacional y de una Constitución liberal que pusiera fin al absolutismo, la Restauración supuso la fragmentación del territorio nacional en treinta y nueve estados particulares que conformaron la Confederación Germánica, y la constitución de un régimen policial represivo para contener las demandas liberales. Sin embargo, la Restauración no consiguió erradicar todas las conquistas y transformaciones que se habían desarrollado: el crecimiento de una gran burguesía, el surgimiento de masas obreras, el empobrecimiento de clases anteriormente estables y ahora desplazadas, como los artesanos o los campesinos, que muchas veces engrosaron las filas del proletariado urbano; la experiencia alienante de la vida en la gran ciudad y la proliferación de medios de comunicación y transporte.

Es decir, mientras que por un lado se asistía a la histórica ruptura con una tradición y 
formas de vida vinculadas al pasado feudal; todo un sistema político pretendió contener ese derrumbe a través de medios represivos y una masiva campaña ideológica. Las consecuencias de este proceso fueron la inseguridad, el desgarro y la duplicidad del sujeto, que se vio impelido a optar entre dos actitudes: aferrarse al pasado o rechazarlo radicalmente en pos de lo nuevo - aún incierto -, apoyándose en las nuevas tendencias de la época. Así, dentro de las nuevas corrientes literarias de la época, caracterizadas todas por el apesadumbrado sentimiento de crisis (Biedermeier - realismo conservador y reaccionario -, Vormarz - por referencia a la revolución de 1848 - y la Joven Alemania), Heine respondió a las tendencias más comprometidas políticamente con la idea nacionalista de unificación alemana y de una literatura crítica respecto al presente, características de La Joven Alemania, aunque con algunos elementos del Biedermeier.

La Joven Alemania defendía un vínculo estrecho entre literatura y periodismo, en tanto procuraba alcanzar, a través de una literatura políticamente comprometida, la libertad política y la transformación del Estado y del individuo en elementos públicos. Por lo tanto, si bien Heine adoptó rasgos de la corriente romántica en sus primeras poesías, a partir de su exilio en París (1831) y de la profundización de la crisis europea, comenzó a definir una nueva función en su obra, logrando una síntesis más acabada entre literatura y política que aquella alcanzada por sus compañeros de la Joven Alemania.

Esto fue así, porque para Heine el Romanticismo se revelaba insuficiente ante la nueva coyuntura histórica, en tanto la crisis política, social y económica fue concomitante a una crisis en el plano de las ideas tanto religiosas como filosóficas, tradicionalmente vinculadas al sistema feudal. En consecuencia, Heine redefinió su obra a partir de la crítica estética a un Romanticismo que concebía como insuficiente y reaccionario, destruyendo la idea de armonía por esta corriente sustentada, y proyectando una estética no conciliatoria, futura y liberadora:

\footnotetext{
Heine destruye conscientemente las ilusiones de las que se sabe preso y a las que, a pesar de todo, se aferra. El abismo que separa el ideal del sentimiento y la vida real se expresa así en la íntima disociación del poeta [...] Pero es también el doble juego de utilizar un lenguaje poético - el romántico -, que ya forma parte de la convención literaria, para expresar determinados sentimientos, y simultáneamente, distanciarse de este lenguaje, marcando así la distancia respecto al período literario anterior (FORTEA, 1995, p. 17).
}

\section{Interpretación estética de la realidad política: El desgarro espiritualismo-sensualismo}

Para un poeta políticamente comprometido con su presente histórico como lo era Heine, la literatura debía tener una clara función política, siendo consciente de la estrecha 
relación existente entre las corrientes filosóficas y estéticas, y la realidad política de cada época. Es decir, Heine no concebía la idea de un arte separado de la realidad histórica (lo cual se observa en sus múltiples ensayos y artículos periodísticos de reflexión estética y política); sino por el contrario, las disputas estéticas que Heine establece dentro de sus textos dialógicos entre pasado y presente (solapadas por el uso de la ironía pocas veces apreciado por los críticos), subsumen una tesis de contenido político riguroso, demostrando hasta qué punto arte y política son movimientos paralelos. Por ende, para Heine, plantear un proyecto estético nuevo en base a la crítica de un modelo anterior es proponer al mismo tiempo, una nueva perspectiva política de la realidad.

La dimensión política que reside en la concepción estética del arte en Heine se vincula con su simpatía por la corriente Saint-simoniana del socialismo utópico. Lukács sentencia que, en Heine, el socialismo no aparece como un proceso histórico concreto sino por el contrario como proyecto futuro, y esta idea de proyecto utópico futuro irrealizado se traslada a su concepción del arte venidero. Así, para Lukács esto se debe a la síntesis que opera Heine entre la doctrina saint-simoniana y la de Hegel, que lo conduce a radicalizar los elementos conservadores de esta última. Pues, si para Hegel el cristianismo suponía una superación necesaria de la Antigüedad en tanto remisión a un Dios mortal, a diferencia de los dioses paganos inmortales, Heine toma el atenimiento al más acá y rechaza la idea de redención futura del cristianismo a favor de una recompensa en vida. Para ello, le opone un componente de sensualidad propio de la doctrina Saint-simoniana. Es decir, ante el ascetismo e idealismo profesado por Hegel como progreso en relación a la Antigüedad, Heine opone la visión sensualista profesada por los Saint-simonianos, en la medida en que ve que frente a la unidad de materia y espíritu sostenida por el mundo clásico, la división establecida por el cristianismo entre ambos elementos ha dado lugar, por un lado, a la condenación de la materia, el cuerpo, y por otro, a una exaltación del espíritu, de lo extraterrenal. Algo que para Heine también tiene dimensiones político-sociales, pues en el postulado desprecio de los bienes materiales, no sólo ve la mejor causa de las desigualdades sociales, sino también el mejor apoyo al despotismo.

En consecuencia, el intento superador de la doctrina hegeliana a partir de su síntesis con elementos de la doctrina de Saint-Simon, implica en primer lugar, una crítica al cristianismo por su exaltación a un más allá religioso; y en segundo lugar, una tendencia paradójicamente atea y panteísta que opone un más acá terreno y revolucionario, como estadio previo a la revolución social: “consideró al panteísmo sensualista como la religión 
irreligiosa y atea de la era universal, como la visión del mundo, en fin, que en sí misma concertaba lo positivo del viejo materialismo y lo positivo del hegelianismo reinterpretando revolucionariamente, superando, a un tiempo, las faltas y limitaciones de ambos" (LUKÁCS, 1970, p. 126).

Ahora bien, este hegelianismo saint-simoniano descansa en la concepción de Heine respecto de la historia política de los tiempos modernos como una lucha entre espiritualismo y sensualismo. Es decir, Heine percibía a las revoluciones y a los cambios históricos principalmente como transformaciones religiosas y filosóficas, es decir, espirituales:

De hecho, dado que siempre, después del curso de una serie de siglos, aparece en el mundo una nueva religión $\mathrm{y}$, al trasladarse a las costumbres, pone también en vigencia una nueva moral, todas las épocas deberían declarar heréticas e inmorales las obras artísticas del pasado, si las mismas debieran ser juzgadas de acuerdo con los parámetros de la moral de la época (HEINE, 2007, p. 77).

Por lo tanto, a la luz de una época de crisis que hacía pensar en la necesidad de una nueva religión y moral, a partir de la dicotomía sensualismo-espiritualismo Heine aborda una crítica a la escuela romántica, y al hacerlo prolonga una crítica respecto del presente político de Alemania: "El romanticismo intenta perpetuar la situación miserable, servil y escindida de Alemania [...] glorifica la Edad Media, el catolicismo y más tarde, incluso el Oriente, con el fin de crear un modelo ideológico-poético para la conservación de las miserables circunstancias alemanas" (LUKÁCS, 1970, p. 135).

Heine percibe su literatura como un período de transición hacia una nueva estética, que se funda en una crítica tanto hacia el Clasicismo alemán como del Romanticismo. Es el primer crítico alemán consciente del carácter políticamente indiferente del Clasicismo, y del carácter burgués del movimiento romántico, que limita la literatura a una función meramente estética, con el retorno a la poesía espiritualista de la Edad Media, que la Reforma había desdeñado a partir de la revalorización de la materia y el sensualismo de los dioses griegos. Así, el Romanticismo implica para Heine, el retorno al cristianismo característico del medioevo, por su arraigo en un pasado idealizado y en una idea de trascendencia; y por su consecuente indiferencia frente a las problemáticas del presente:

Tal como el cristianismo espiritualista fue una reacción frente al brutal señorío del materialismo del Imperio Romano, tal como el renovado amor al sereno arte griego y a su ciencia debe ser considerado como una reacción frente al espiritualismo cristiano degenerado hasta las más estúpida mortificación, tal como el nuevo despertar del Romanticismo medieval puede verse como una reacción contra el insípido afán de imitación del arte clásico antiguo, así vemos ahora una reacción contra el restablecimiento de aquel modo de pensar católico-feudal (HEINE, 2007, p. 64). 
En esta última cita se observa la perspectiva de evolución dialéctica del arte a partir de la tensión entre espiritualismo y sensualismo, característica de Heine; quien denunció en el período de crisis en el cual escribió, la necesidad del retorno a los valores materiales encarnados emblemáticamente en los dioses griegos, y ya no en el monoteísmo cristiano. La reivindicación de estos dioses, reproduce la tensión entre paganismo y cristianismo, al presentarlos más humanos, vinculados a lo instintivo y material, y por lo tanto, exiliados, vencidos, devenidos espectros al igual que gran parte de la sociedad marginada de la época:

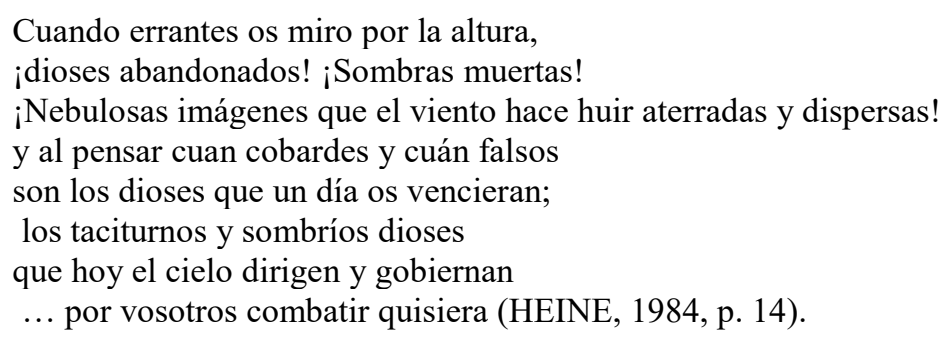

Sin embargo, Heine siente una inclinación por los dioses griegos no sólo por lo que representan en términos de la reivindicación del sensualismo hedonista, sino en la medida en que se han convertido en víctimas de los nuevos dioses, quienes los han relegado a la condición de espectros. Esto evidencia el potencial crítico que, en la obra de Heine, asumen las figuras marginadas, como contrapartida al espiritualismo del Romaticismo y del Antiguo Régimen, y al "vulgar" materialismo burgués del presente:

Los dioses paganos y los espectros del cristianismo encierran para Heine un elemento utópico: encarnan las demandas incumplidas de la humanidad, el principio del placer que reclama una satisfacción plena. La posición dialéctica de Heine se entiende bien cuando se piensa que, en obras en que el escritor cuestiona el espiritualismo del ancien regime, el demonio aparece cargado de un potencial crítico positivo (VEDDA, 2008, p. 158).

\section{Los tres relatos de Heine: el desgarro como fragmentación}

La mayor parte de las obras escritas por Heine en la década del treinta fueron publicadas dentro de los cuatro tomos de su obra Salón, que reúne ensayos, prosa y poesía. Los tres únicos escritos en prosa narrativa de ficción de Heine se encuentran dentro de esta obra integral, y son: De las memorias del señor de Schnabelewopski, publicado en 1833 en el primer tomo, Noches Florentinas de 1835 publicado en el tercer tomo, y El rabino de Bacherach de 1840 publicado en el cuarto tomo. Los tres textos problematizan la tensión entre espiritualismo y sensualismo, no sólo en términos de los contenidos que manejan, sino que tal tensión también define la estructura de contrastes entre espacios y personajes que delinean los relatos. Pues, si bien es cierto que la estructura antitética es un rasgo típico de la 
novela corta, porque permite evitar la justificación psicológica, brindándole al texto una idea de clausura y permitiendo la brevedad característica del mismo; la estructura antitética en los relatos de Heine remite principalmente a la idea de desgarro de una época, y procura anular las armonías y conformismos de la literatura romántica, al reflejar las contradicciones de la realidad política.

Este desgarro estructural que caracteriza a los tres relatos da como resultado una composición episódica, de transposición de escenarios, inclusión de sueños y disgresiones que hacen pensar en una estructura fragmentaria. Esta, sin embargo, no carece de cohesión gracias al uso de la ironía, y en tanto remite a la intención de reflejar la ausencia de armonía de la coyuntura en la cual fueron escritos:

Ya Hegel había advertido que, en una sociedad burguesa que se descompone en intereses particulares, el arte no puede recuperar la cohesión perdida por medio del simbolismo estético de la forma: la evolución histórica ha de tener como consecuencia en el arte la parcelación, lo episódico, lo fragmentario y la exposición de detalles (FORTEA, 1995, p. 47).

Un motivo en común que hilvana los distintos fragmentos o escenas de los relatos es el del viaje, que refleja el carácter cosmopolita de la literatura de Heine. El viaje como búsqueda, huida, y acceso a otro orden; que aparece representado en términos de desplazamiento geográfico, en De las memorias del señor de Schnabelewopski y en El rabino de Bacherach. Por el contrario, en Noches Florentinas, el desplazamiento se produce a través del sueño, la fantasía/narración y la memoria, aunque también se repiten estos últimos motivos en los otros dos relatos. Así, está presente en los textos la alternancia de ciudades y el desplazamiento dentro de tales espacios hacia dimensiones de representación vinculados a motivos fantásticos, tales como espectros, o fantasmas, que se relacionan con las problemáticas de representación que supone la antítesis espiritualismo-sensualismo.

\section{De las memorias del señor de Schnabelewopski: EI desgarro como viaje frustrado}

El relato pone en escena una especie de viaje iniciático que comienza en Hamburgo y culmina en Leyden. Se trata de un viaje a través de un presente escindido entre el sensualismo material de Hamburgo, vinculado a la juventud, y el espiritualismo intelectual de Leyden, asociado a la madurez. Sin embargo, este desgarramiento de la realidad prosaica, se halla presente también dentro del propio personaje, quien no logra conciliar las imágenes oníricas que encierran lo sensual reprimido, con la realidad represora que vive. Así, aún antes de emprender el viaje, el protagonista refleja esta escisión en su propia infancia. La madre aparece retratada como la figura ilustrada $\mathrm{y}$, en consecuencia, con cierta dimensión 
revolucionaria, en contraposición al padre que representa la moral económica del materialismo capitalista.

En este sentido, las figuras femeninas en los relatos de Heine presentan un sesgo de utopía en la medida en que se vinculan con motivos marginales (sensuales, oníricos) y entran en contradicción con el sistema imperante, vehiculizando de esta manera, una crítica tanto estética como política:

Mi madre... había leído mucho; mientras estaba encinta de mí, leía casi exclusivamente a Plutarco... De ahí mi místico anhelo por llevar a la práctica la Ley Agraria en forma moderna. Quizá mi sentido de la libertad y la igualdad deba atribuirse a tales lecturas maternas. Si por entonces mi madre hubiera leído la vida de Cartuch, quizá hubiera llegado a ser un gran banquero (HEINE, 1996, p. 123).

En la cita se pone en evidencia la idea de la educación como condicionamiento ideológico del individuo, al mismo tiempo que se refleja la inclinación del personaje hacia lo femenino, vinculado con lo revolucionario; por oposición al padre: "me dio una larga carta en la que había escrito, artículo por artículo, la forma en que había de comportarme en este mundo. El primer artículo decía que había de dar diez vueltas a cada ducado antes de gastarlo" (HEINE, 1996, p. 124).

En este momento previo al viaje, el protagonista tiene primero un recuerdo y luego un sueño que evidencian la condición desgarrada del individuo entre cuerpo y espíritu. El recuerdo mezcla la imagen de San Adalberto en la catedral de Gnesen, con la mirada de una mujer que despierta el deseo sensual en el protagonista. No en vano Heine utiliza la imagen de San Adalberto (apóstol de Polonia, Hungría y Prusia), ya que su vida representa la intransigencia espiritual, la exaltación de lo divino, la contemplación y la vida en el claustro, que suponen la no conciliación con el mundo humano: "En mi espíritu tan tenebroso como el mar, ese rayo de luz despertó todos los monstruos que dormían en el profundo abismo, y los enloquecidos escualos y tiburones de la pasión se alzaron de pronto, y se agitaron, y se mordieron de placer las colas" (HEINE, 1995, p. 124). Las mismas imágenes de San Adalberto y la mujer reaparecen en el sueño posterior, con el cual se inicia el viaje. En esta escena onírica, San Adalberto reaparece en un paraje paradisíaco pero con una postura recriminatoria: "me gritó con horrorísima voz de plata" (HEINE, 1995, p. 125). De esta manera, el paraíso se nubla pero trae en recompensa una figura femenina fantasmal y marmórea, que compensa el deseo sensual reprimido por la religión: "El bote, con sus fantasmales remeros, se lanzó de vuelta a alta mar como una flecha, y en mis brazos estaba Panna Jadviga, y lloraba y reía: te adoro" (HEINE, 1995, p. 125). Sin embargo, la figura femenina, emblema de lo sensual en los relatos de Heine, sólo puede aparecer en términos 
espectrales e intangibles, en la medida en que la exaltación de lo espiritual no permite la realización de la sensualidad de la materia. Esta particularidad en las representaciones femeninas se presenta como una operación crítica de Heine, pues ironiza respecto a las imágenes femeninas estériles del Clasicismo y del Romanticismo. Operación que también se evidencia en los otros dos relatos.

Ahora bien, en Hamburgo las figuras femeninas son paradigmas de la sensualidad de la ciudad, y entran en contradicción con las figuras femeninas románticas que desdeñan la sensualidad del cuerpo:

Si en el amor romántico no se muestran demasiado soñadoras, y saben poco de las grandes pasiones del corazón, no es culpa suya sino culpa de Amor, el diosecillo que a veces coloca en su arco las flechas más agudas, pero sea por malicia o por torpeza dispara demasiado bajo, y en vez del corazón de las hamburguesas sólo suele alcanzar a su estómago (HEINE, 1995, p. 128).

En Hamburgo prima la necesidad material de la alimentación, es el centro de lo mundano, y allí Heine apela a un recurso recurrente en sus relatos: representa la sensualidad femenina a partir de divinidades paganas, por oposición a las mujeres espiritualizadas del romanticismo: "Por ahí vienen las sacerdotisas de la diosa surgida de las olas, hanseáticas vestales, Dianas de caza, náyades, Dríades, hamadríades y demás hijas de predicador" (HEINE, 1995, p. 133). Empero, no escapa la crítica al presente en esta crítica estética. El pasado sensual que el protagonista recuerda como parte de sus memorias de viaje de juventud, entra en contraste con un presente decadente, adulto y corrompido por el materialismo vulgar del incipiente sistema capitalista, en donde las individualidades devienen figuras algebraicas, números, autómatas, y la sensualidad se torna inmaterial: "Heloise, el delicado ser que parecía hecho sólo para flotar sobre alfombras indias de suaves flores y ser abanicadas por plumas de pavo real, se hundió entre ruido de marineros, ponche, humo de tabaco y mala música" (HEINE, 1995, p. 134).

En este punto se comprende el uso intertextual de la leyenda danesa de Volved y la leyenda del holandés errante (que parecerían brindar un carácter fragmentario al texto). Ambas remiten al motivo del viaje como salida al mundo para develar sus enigmas, pero esta salida al mundo resulta en un fracaso: "el pobre barquichuelo naufraga entre románticos escollos o embarranca en arenas insulsas y prosaicas" (HEINE, 1995, p. 144). Esto es así, porque Volved asesina a su madre junto con la figura femenina traidora de la bruja, y el holandés errante es traicionado por una mujer. Heine ubica, irónicamente, a la figura sensual de la mujer como fuente de perdición del hombre: "la moraleja de la obra es, para las mujeres, que tienen que tener cuidado de no casarse con ningún holandés errante; y nosotros, los 
hombres vemos en esta obra cómo por las mujeres, en el mejor de los casos, nos vamos a pique" (HEINE, 1995, p. 151). Es decir, parecería ser que ni la aventura hedonista de Hamburgo, ni el espiritualismo de Leyden, conducen a la felicidad plena, y de ahí las imágenes de errancia, de búsqueda continua, de viaje frustrado. Las relaciones amorosas o afectivas que recorren tanto la realidad del protagonista como las leyendas que intercala, evidencian el carácter desgarrado del sujeto que no logra conciliar materia y espíritu, revelando el carácter contradictorio de la realidad.

Pues en Leyden (destino final del viaje para estudiar teología), el amor se convierte en un valor de intercambio para conseguir alimento: "Pero si la cocina resultaba escasa varios días seguidos, me veía asediado por las más graves peticiones; que consiguiera mejor comida, que inflamara de nuevo el corazón de la posadera" (HEINE, 1995, p. 154). Es decir, nuevamente la necesidad material desmiente el ideal de amor romántico y espiritual, ya que los cuerpos se confunden con la comida: "Van Moeulen era también un hombre hermoso, un Apolo, pero no un Apolo de mármol, sino más bien de queso" (HEINE, 1995, p. 158). Sin embargo, Leyden se presenta como el escenario de la espiritualidad en contraposición a Hamburgo, ya que el protagonista se relaciona con un grupo de estudiantes que reproducen nuevamente la tensión entre espiritualismo y sensualismo: Simson el judío, teísta, y racional se contrapone al personaje de Jan Steen, el pintor irónico que se apropia con humor de las escenas religiosas, reproduciendo el uso de la ironía de Heine en su propia obra. Así, el espiritualismo de Simson se contrapone en Leyden al sensualismo hedonista de Jan Steen: "No era un espectro católico lúgubre, sino un moderno y luminoso espíritu de la alegría, que después de muerto visitaba aún su antiguo estudio para pintar alegres cuadros y beber" (HEINE, 1995, p. 161). En este sentido, la figura del pintor encarna la alternativa superadora de la dualidad, la idea de utopía futura: "la figura de Jan Steen, que aparece como encarnación del ideario Saint-simoniano del escritor, y por tanto, como exponente de una sensualista promesse de bonheur" (VEDDA, 2008, p. 160).

Por ello, la muerte final de Simson evidencia la puesta en crisis del ideal espiritualista. Y esto, no sólo por la muerte del único defensor del teísmo, sino también porque las discusiones de tinte espiritual se producen sólo en la medida en que los estudiantes no consiguen satisfacer sus necesidades materiales de alimentación y deben encontrar un pasatiempo para distraerse. En definitiva, parecería ser que las diferencias teológicas están condicionadas por fundamentos materiales.

Nuevamente, en el desenlace del relato, la figura femenina actúa como 
desencadenante de la caída del hombre, como en las leyendas anteriores y en la de Sansón; ya que es la posadera quien no les sirve la comida y desata la disputa:

La Historia está llena de ejemplos de cómo nos hundimos por causa vuestra. Todos vuestros actos son insensatos, ingratos todos vuestros pensamientos. Os damos lo más alto, la llama más sagrada del corazón, nuestro amor... ¿y qué nos dais a cambio? Carne, mala carne de vaca, peor pollo... (HEINE, 1995, p. 170).

Ante este estado de cosas, el relato propone al plano onírico como el ámbito de felicidad en el cual afloran todos los deseos reprimidos por el plano de la realidad prosaica. Tal es el caso del marido de la posadera, quien se apropia en sus sueños de las figuras espirituales de la Biblia, y las sensualiza, hasta el punto que el plano del sueño invade la realidad, en tanto la posadera se pone celosa de esas configuraciones nocturnas del marido y termina censurándolas. Esta situación le permite al protagonista reflexionar acerca de la existencia de los sueños como consecuencia de la separación instaurada por el cristianismo, entre espíritu y materia:

\footnotetext{
¿Acaso no es terrible que el cuerpo pueda estar como un cadáver una noche entera, mientras el espíritu lleva a nuestro ser la más agitada de las vidas, una vida con todos los horrores de la separación que hemos creado entre cuerpo y alma? Si algún día, en el futuro, ambos vuelven a unirse en nuestra conciencia, quizá ya no haya sueños, o solamente sueñen los enfermos, aquellos cuya armonía esté perturbada (HEINE, 1995, p. 164).
}

Este desgarro que atraviesa al sujeto justifica las representaciones irónicamente espectrales que asumen las figuras femeninas en los relatos de Heine, en la medida en que son seres despojados de su materialidad, procurando vivir sólo en términos espirituales (igual que las representaciones femeninas del Romanticismo): "Nuestra época - que comienza con la cruz de Cristo - será contemplada como un gran período enfermizo de la Humanidad" (HEINE, 1995, p. 164).

\section{Noches Florentinas: El desgarro como enfermedad}

La condición enfermiza de la era moderna aparece claramente representada en el relato Noches Florentinas. Aquí, la narración se propone como paliativa ante el presente enfermo, de la misma manera en que en el relato anterior aparecía el sueño sensualista. Ahora bien, la división que en el relato anterior se instauraba dentro de cada individuo durante el sueño, entre el cuerpo inmóvil y el espíritu liberado, aparece ya en Noches Florentinas totalmente desgarrado, en la medida en que la enferma como puro cuerpo, yace inmóvil y sin habla, y el narrador Maximiliano como puro espíritu, da rienda suelta a su imaginación. Es decir, en Noches Florentinas como refería la cita anterior, no es el enfermo quien sueña, sino 
el narrador, en tanto su condición de sujeto desgarrado niega toda armonía posible, asumiéndose como la verdadera enfermedad: la enfermedad de la primacía del espíritu por sobre la materia. Esta es una primera operación de crítica de Heine a la literatura pretendidamente armónica del Romanticismo, en la cual aquel que soñaba se dejaba arrastrar por la fantasía. Contrariamente, en Noches Florentinas, es el despierto en su calidad de sujeto desgarrado quien debe dejarse llevar por la fantasía. Así, si en un primer plano de representación, Heine realiza una crítica al presente; en un segundo plano, realiza una crítica estética que también tiene directa remisión a la dimensión presente. Por lo tanto, los motivos que caracterizan las narraciones de Maximilano, en un segundo nivel de representación, son también espectrales, nocturnos y fantasmagóricos, es decir, carentes de corporalidad al igual que en De las memorias del señor de Schnabelewopski. Aunque en este último relato, el sueño conserva cierto carácter de utopía pues retrata un mundo no totalmente enfermo, mientras que en Noches Florentinas, la muerte y la enfermedad parecen haberlo invadido todo, todo es oscuridad y configuraciones nocturnas, desde el propio título.

La tensión entre espiritualismo y sensualismo se evidencia en este relato a partir de la oposición entre el personaje de Maximiliano y el del doctor, pero ante todo y desde el título, en la misma ciudad de Florencia donde se sitúa el primer nivel de representación de la narración y que resume tal tensión: "Manfred Windfuhr señala que en la ciudad, según la concebía Heine, 'se unen fuerza y gracia, Antigüedad y Edad Media (...) Lo que en otros sitios sólo aparece separado, aquí está fusionado." (VEDDA, 2008, p. 157). El relato se desarrolla, por indicación del título, en Florencia. Aunque no hay tales indicios espaciales en la obra. Por el contrario, a través de las narraciones de Maximiliano el relato se desplaza hacia otros espacios pero ya en un segundo nivel de representación. Esta duplicidad en los niveles narrativos se reproduce también en la estructura del relato, que se divide en dos noches, y cuya duplicidad remite a la existencia de dos órdenes que se oponen a su vez en cada nivel narrativo: el de la realidad prosaica, enferma, y el de la narración, la fantasía o el sueño.

Por lo tanto, en el primer nivel, aquel en el cual Maximiliano obra como narrador y no como protagonista de los hechos, su función es la del esteta sensualista que se deleita en la contemplación del cuerpo femenino de María: "En silencio, cruzado de brazos, Maximiliano permaneció algún tiempo de pie ante la mujer dormida, contemplando los hermosos miembros..." (HEINE, 1995, p. 180). Contrariamente, el médico representa el discurso burgués y racional, por su afán de optimizar el tiempo (elemento fundamental del sistema capitalista), y legitima el discurso fantástico de Maximiliano al pautar su inicio y desenlace, 
brindándole un marco de verosimilitud. Empero, su propia imagen contiene paradójicamente algo del orden de lo fantástico: sus guantes negros y su enfermera Deborah, también negra y silenciosa casi como un espectro: "La Negra Deborah, con su finísimo oído, había reconocido por el andar al recién llegado y le abrió suavemente. A una señal, abandonó la estancia silenciosamente" (HEINE, 1995, p. 179).

En consecuencia, mientras Maximiliano se deleita contemplando la corporalidad casi agonizante de María, el doctor desdeña el recuerdo material de una mascarilla de yeso, por ser incapaz de conservar lo verdaderamente trascendente de una persona, su espíritu: 'Los moldes de yeso son verdaderas caricaturas de rostros cuyo encanto era más de orden espiritual [...] tan pronto se han extinguido las gracias de la vida, las desviaciones reales de las líneas ideales de belleza ya no se ven compensadas por el encanto espiritual” (HEINE, 1995, p. 207).

En el segundo nivel narrativo, si bien Maximiliano se convierte en protagonista de lo narrado, no modifica su rol de esteta pues sus relaciones amorosas son meramente espirituales, y de ahí su inclinación hacia figuras femeninas espectrales o muertas. Con lo cual se observa la impronta de desilusión que alberga este relato, en el cual ni siquiera a través de la fantasía, el sueño o el recuerdo, el sujeto logra evadirse del desgarro que lo torna tan inactivo y estéril como las propias imágenes femeninas que contempla.

Hay en la primera noche una progresiva espiritualización en la representación de las figuras femeninas: la enferma, la madre, la estatua de mármol caída, el retrato, el recuerdo de Very y finalmente, la verdadera alma gemela: la mujer soñada. Esta última es aquella que representa a la mujer como puro espíritu, sin materialidad posible: "era más un alma que un rostro" (HEINE, 1995, p. 189), y de ahí la ausencia de tacto y de sensualidad: "casi como hermano y hermana. A veces ni siquiera hablábamos, y nos mirábamos el uno al otro a los ojos, y en esa deliciosa contemplación pasábamos eternidades enteras" (HEINE, 1995, p. 189). Todas estas figuras femeninas aparecen en espacios decadentes y enfermos, acentuando la idea de fantasmagoría de la materia: un sanatorio, un palacio en ruinas, un bosque diezmado y el sepulcro de la capilla de los Medicis (aquí aparece la idea de muerte de la materia asociada a la religión).

Maximilano imprime sensualidad a estas representaciones femeninas, pero se trata de una sensualidad derribada por la primacía del espíritu, y de ahí la inconcreción física del amor: "yacía sin mutilación alguna, una diosa de mármol, de purísimos rasgos y nobles senos netamente partidos, que se destacaba brillando entre las altas hierbas como una aparición griega" (HEINE, 1995, p. 183). En esta última cita se pone en evidencia la mutilación de los 
senos de la estatua como la represión de lo sensual femenino, al mismo tiempo que Maximiliano le sobreimprime la sensualidad propia de las divinidades paganas en contraposición a los "espectros" del cristianismo. Esta inclinación del deseo del narrador hacia lo inmaterial (desdeña a las mujeres de carne y hueso de la realidad prosaica), es la manera a través de la cual Heine vehiculiza una crítica a la escisión operada por el cristianismo entre materia y espíritu, como se vio en el relato anterior: "En la medida en que los tiempos modernos están marcados, según Heine, por el triunfo del espiritualismo, lo material y lo corpóreo tiene que verse sometido a la corrupción y a la muerte" (VEDDA, 2008, p. 162).

Por esta misma razón el narrador se siente atraído hacia la música italiana, pues en ella hay más espíritu que materia, y las figuras de los músicos son tan inmateriales como las figuras femeninas: “Aquí en Italia la música no está representada por individuos, sino que se manifiesta en toda la población, la música se ha hecho pueblo" (HEINE, 1995, p. 192). Así, la admiración por Bellini comienza días antes de su muerte, cuando la corporalidad se enferma: "En ese momento Bellini se me apareció como tocado por una varita mágica, como transformado en una figura amiga" (HEINE, 1995, p. 196). Mientras que la admiración por Paganini es constante por el aspecto de moribundo que presenta: "el viejo y descolorido Paganini siempre tenía el aspecto de un moribundo" (HEINE, 1995, p. 197).

Ahora bien, la música de Paganini le permite a Heine poner en escena el potencial revolucionario del arte, en la medida en que su música se convierte en puros signos transfiguradores de la realidad, y por esta capacidad, asume representaciones monstruosas y diabólicas. Hasta la misma imagen de Paganini se convierte en la de un mago o un brujo: "de las rojas olas de sangre vi emerger las cabezas de los demonios desencadenados: monstruos de fabulosa fealdad, cocodrilos con alas de murciélagos" (HEINE, 1995, p. 205). Sin embargo, si en un primer momento Maximiliano debe cerrar los ojos y cubrirse los oídos para reprimir estas representaciones diabólicamente materiales; en un segundo momento, la música y el mismo Paganini se transforman en imágenes espiritualizadas. Con lo cual, Paganini y su música adquieren los rasgos del espiritualismo sensualista de los dioses griegos, resumiendo el ideal Saint-simoniano del arte, al igual que en el relato anterior lo hacía el personaje de Jan Steen: "un indecible ardor habitaba aquellas notas, que a veces temblaban apenas audibles... para hervir por fin con júbilo desenfrenado" (HEINE, 1995, p. 206). Paganini caracteriza el ideal de utopía estética de Heine, en tanto concilia armoniosamente espíritu y materia en su arte. Esta conciliación es la misma que caracteriza la leyenda fáustica que se le adjudica a 
Paganini:

Aquel sabio doctor Fausto, aquel espiritualista que comprende mediante el espíritu la insuficiencia del espíritu y exige los placeres materiales, y restituye sus derechos a la carne; sin embargo, atrapados todavía en la simbología de la poesía católica, en que Dios es considerado el representante del espíritu y el diablo, el representante de la carne, se consideró aquella rehabilitación de la carne como un rechazo a Dios y un pacto con el diablo (HEINE, 2007, p. 87).

La capacidad transfiguradora de la realidad que asume el arte en el relato se prolonga en la segunda noche a través del personaje femenino de Lorenza. Su personaje encarna la libertad, la juventud, y la utopía estética futura a través de su danza no ortodoxa vinculada a la naturaleza, en tanto deviene signo/enigma por develar. En este sentido, el personaje permite unificar dos motivos presentes en el relato: el arte y lo femenino, que en sus representaciones aparece como una prolongación de lo estético. De esta manera, el arte nuevo que representa la danza de Lorenza contrasta con al materialismo vulgar de Londres; ciudad que asume las mismas características que Hamburgo en el relato anterior, pues prima allí la materialidad, el tedio, la vulgaridad y la hipocresía que supone el cristianismo, en tanto remite a un culto espiritual y desligado de lo material, dando como resultado la situación contraria: "la madera, el hierro y el latón parecen haber usurpado allí el espíritu del hombre, y haberse vuelto locos de plenitud espiritual, mientras el hombre, privado de su alma, como un hueco fantasma, hace sus tareas habituales como una máquina” (HEINE, 1995, p. 212).

No es casual que Heine utilice la danza como emblema del arte nuevo, en la medida en que la danza implica la armonía entre cuerpo y música/espíritu, y es también aquella disciplina artística que en Francia se conserva igual que antes de la Revolución. Este vínculo que sostiene el arte nuevo con el pasado se evidencia en primer lugar a partir de la relación que sostiene Lorenza con personajes emblemas del pasado político de Francia: el enano caricatura de una aristócrata francés, una madre francesa grotesca y viuda, y un perro amaestrado por los franceses, que representa al ejército ingles apoyado por la aristocracia francesa para derrocar a Napoleón. En segundo lugar, se evidencia a partir del contacto que la danza de Lorenza tiene con la Tierra, como la voz de su pasado, como el origen fingido, ya que se trata de la voz del ventrílocuo y no de la verdadera voz materna. Es decir, en Londres, en un primer momento, la danza de Lorenza es consciente y es un acto de rebeldía hacia ese pasado feudal, en una búsqueda de contacto con el origen, la Tierra; pero también supone una superación de ese origen, en tanto realiza un gesto de lavarse las manos, como desprendimiento del pasado: 
nada de medieval, ni de veneciano, ni de macabro, no había en ella ni Luna ni incesto. Era un baile que no pretendía distraer con las formas de sus movimientos externos, sino que sus movimientos externos parecían palabras de un lenguaje especial, que quería decir algo especial. Pero, ¿Qué decía ese baile? Yo no podía entenderlo (HEINE, 1995, p. 216).

Por el contrario, en un segundo momento y bajo la monarquía de julio, Lorenza casada con un oficial bonapartista y habiendo vencido a ese pasado, continúa bailando la misma danza pero de manera automatizada, como si se tratara de un proceso inevitable de evolución histórica: "su baile tenía entonces algo de embriagada involuntariedad, algo de tenebrosa inevitabilidad, algo fatal; en esos momentos, bailaba como el destino" (HEINE, 1995, p. 217). En este sentido, Heine propone una idea de arte nuevo aún indefinido pero inminente, de ahí la constante referencia a la calidad enigmática de su danza. Un arte que restituya la armonía entre cuerpo y espíritu, a partir de una relación con el pasado y su consecuente superación. Empero, en Noches Florentinas ese proyecto permanece aún como utopía, transición, irrealizado, y en consecuencia, inmaterial, enigmático y espectral, como la propia Lorenza: "me pareció ser el Dios Plutón que, rodeado de llamas infernales, sostenía en sus brazos a la durmiente Prosperina ¿Qué significaba esa mujer? ¿Qué sentido se escondía bajo el simbolismo de esas bellas formas?” (HEINE 1995, p. 237).

Por esto, en los relatos de Heine música, danza y femineidad adquieren una dimensión crítica y revolucionaria: "La significación política de la danza de Lorenza se torna más visible cuando se tiene en cuenta que, como dice Höhn, música y danza aparecen en Heine como expresión del deseo de libertad de los pueblos oprimidos o como cifras políticas" (VEDDA, 2008, p. 160).

\section{El rabino de Bacherach: el desgarro como decadencia religiosa}

En este relato, Heine se adentra en las problemáticas del pueblo judío como paradigma del espiritualismo, de la misma manera que el personaje de Simson en De las memorias del señor de Schnabelewopski: "Los judíos son siempre los teístas más sumisos... En cuestiones políticas, son tan republicanos como imaginarse pueda,... pero cuando se tocan conceptos religiosos, se mantienen esclavos sumisos de Jehová, el viejo fetiche, que ya no quiere saber nada de toda su estirpe y se rebautiza en un Dios de puro espíritu" (HEINE, 1995, p. 157). El espiritualismo se evidencia a partir de la función que asume el alimento en la celebración de las Pascuas. En esa escena, el alimento no tiene una función material de alimentación como en los relatos anteriores, por el contrario, para los judíos asume un valor simbólico dentro de un ritual. Sin embargo, se trata de un espiritualismo que contrasta con un 
presente enfermo y decadente, porque los judíos son retratados como un grupo de individuos aislados, que conservan una identidad común dentro de una coyuntura de fragmentación nacional, y por lo tanto, son marginados y perseguidos: "yo creo que este Dios puro espíritu, este advenedizo del cielo, ahora tan moral, tan cosmopolita y universal, alberga una secreta malquerencia contra los pobres judíos" (HEINE, 1995, p. 157).

La primera ciudad que aparece retratada es Bacherach, y se la presenta como una ciudad en ruinas a causa de los anteriores regímenes imperiales, pero de cierta libertad política e internamente escindida: "Pero cuanto más los apremiaba el odio desde fuera, más íntima y cordial se hacia la convivencia familiar, más hondo enraizaban la devoción y temor a Dios de los judíos de Bacherach" (HEINE, 1995, p. 248). En este sentido, el relato presenta en un primer momento al pueblo judío como las figuras marginales que asumen un carácter revolucionario (en especial el personaje femenino de Sara, a través de la cual se percibe la realidad de la narración), en la medida en que se oponen a un sistema que los hostiga: “¡Este año la celebramos aún como siervos, pero el año que viene lo haremos como hijos de la libertad!” (HEINE, 1995, p. 252). En este primer momento, el espiritualismo del personaje de Rabí Abraham contrasta con el materialismo vulgar de la ciudad de Frankfurt, hacia donde huyen ante la persecución de la cual son víctimas. Ya que mientras en Frankfurt, prima nuevamente la necesidad material del alimento, el rabino se desprende de lo material, huye de su pueblo dejando todas sus pertenencias, y arroja el aguamanil de plata, como interrupción del ritual alimenticio: "para que la desgracia no nos persiga he lanzado al río la última de mis posesiones, el aguamanil de plata para apaciguarla” (HEINE, 1995, p. 256).

Por lo tanto, la ciudad de Bacherach es representada como un espacio de mayor armonía espiritual dentro de la comunidad judía (de ahí la presencia del nombre de esta ciudad en el título), mientras que el desplazamiento de la acción hacia la ciudad de Frankfurt supone su desgarramiento. Es decir, en la ciudad de Frankfurt, donde prima la opulencia, lo sensual, lo material en términos de mercancías seductoras, y la multitud de la gran ciudad; se evidencia una segunda representación de la condición espiritual de los judíos. Aquí, éstos se encuentran también marginados en la judería, pero esta marginación asume características grotescas e irónicas, como si el espiritualismo no pudiera deslindarse totalmente de los efectos "nocivos" del materialismo de la ciudad:

Los judíos al multiplicarse mucho en Frankfurt y no poder ampliar su barrio, empezaron a construir un piso encima del otro, se agolparon como sardinas y echaron a perder su cuerpo y alma... La parte de la judería que quedó en pie tras el gran incendio, a la que se llama Callejón Viejo, esas altas casas negras en las que chalanea un pueblo malevolente y húmedo, es un escalofriante monumento a la Edad 
El espiritualismo de los judíos en Bacherach es tan sólo el preludio a la grotesca decadencia espiritual de los judíos de Frankfurt. Pues, la reivindicación de lo espiritual por sobre lo sensual los conduce a aferrarse a un culto del pasado, marginándose de las problemáticas del presente. De la misma manera que el culto al pasado del Romanticismo, suponía, para Heine, una indiferencia respecto de las problemáticas del presente.

Entre medio de estas dos representaciones del ser judío, se ubica el personaje femenino de Sara, quien registra la acción narrada a través de recuerdos, sueños y reflexiones. Este personaje femenino reproduce por momentos el rol de esteta de Maximiliano en Noches Florentinas, ya que todo lo observa sin intervenir. Esto se debe a que presenta una existencia estéril, a causa de la enfermiza condición que supone la separación entre cuerpo y espíritu "Se sentó en el centro del bote, una sollozante estatua de mármol” (HEINE, 1995, p. 256)-, y que la hace acudir a un estado de ensoñación y recuerdos. Es decir, al igual que en los otros relatos, se asiste aquí a un desplazamiento de la acción hacia otras dimensiones de representación (sueños, fantasías, recuerdos), que se contraponen al plano de la realidad prosaica, represora y hostigadora. Así, Sara detenta cierto componente sensualista en sus ensoñaciones y sus deseos, que son reprimidos por el espiritualismo de su marido Rabí Abraham. En un primer momento, en la mesa de Pascua, Sara se evade de la ceremonia espiritual a través de la contemplación de las ilustraciones del Agade, y luego, durante la huída de la ciudad de Bacharach, se evade a través del recuerdo de las narraciones infantiles que le contaba su tía.

En consecuencia, se repite en este relato la idea de la infancia o juventud asociadas a la sensualidad y la felicidad, que se ven reprimidas en el ser adulto, y que en momentos de tensión permanecen como reservorio de fantasías y evasión sensual. Algo que también sucede con el narrador en el relato De las memorias del señor de Schnabelewopski:

\footnotetext{
Entre nieblas, estas imágenes pasaban por la mente de la hermosa mujer; veía como ella y su pequeño primo, ahora tan mayor y su marido, jugaban de niños en una choza de ramas... cómo el pequeño Abraham iba charlando con ella, cada vez más cariñoso, hasta que poco a poco se fue haciendo mayor y huraño, y al final de todo mayor y del todo huraño (HEINE, 1995, p. 258).
}

Por lo tanto, las figuras femeninas conservan un potencial revolucionario en tanto aparecen inclinadas a la fantasía y la sensualidad, de la misma manera que en los relatos anteriores. Sara es estimulada durante su infancia por su Tía, pero la imagen masculina del padre obra como represión: "la hermosa Sara oyó la voz de su padre, que interrumpía 
enfadado a la pobre tía diciendo que no hacía más que meter a la niña tonterías en la cabeza" (HEINE, 1995, p. 257). Lo mismo sucede en la ciudad de Frankfurt, en donde Sara se ve seducida por toda la suntuosidad de los objetos de la feria, que la retrotraen a la infancia, como aquella época más material y sensual: "Las telas de seda y terciopelo, ricamente bordadas, parecían hablar con la hermosa Sara y quererle reflejar toda clase de maravillas en el pensamiento, y ella se sentía realmente como si volviera a ser una chiquilla" (HEINE, 1995, p. 261). En esta escena, nuevamente, la figura masculina de Rabí Abraham obra como represor de la sensualidad: “¡cierra los ojos, hermosa Sara! - dijo el rabino” (HEINE, 1995, p. 264).

Ahora bien, esta contraposición entre lo masculino y lo femenino se reproduce, pero degradada, dentro de la sinagoga que se ubica en la judería de Frankfurt. La judería refleja la condición enfermiza y grotesca que implica la exaltación judeo-cristiana de lo espiritual por sobre lo sensual, dentro de un presente que revela tal escisión como insuficiente. Esto se observa en la puerta doblemente custodiada por cristianos y judíos, como si se tratara de la frontera entre dos dimensiones antagónicas: entre el espiritualismo de la pareja Sara-rabino y la deformación espiritual y grotesca de los guardianes judíos, y entre el antisemitismo del guardián cristiano y los judíos:

\footnotetext{
El carácter dual de esta escena queda sintetizado en la canción de la cabrita, en la que, como en un juego, se expone la inacabable cadena de devorar y ser devorado: es la bufonada como recurso para ocultar lo difícil que en el presente narrativo - y en el presente de Heine- resulta creer en la intervención divina prometida por el Antiguo Testamento (FORTEA, 1995, p. 78).
}

Esto último se confirma, pues Heine elimina en el final de la canción de la cabrita a la presencia redentora de Dios exterminando al ángel de la muerte. Así, la canción concluye sólo con el ángel de la muerte, clausurando la idea de redención espiritual o divina, lo cual pone en evidencia, al igual que en los relatos anteriores, la crítica de Heine al espiritualismo: “¡Mira bella Sara - dijo suspirando - cúan mal guardado está Israel! ¡Falsos amigos cuidan sus puertas desde fuera, y dentro sus guardianes son la locura y el miedo!" (HEINE, 1995, p. 272).

La sinagoga reproduce la imagen grotesca de la judería, en tanto Heine juega irónicamente al nombrar a los judíos con nombres de animales. Allí, las mujeres se ubican en las alturas, mientras los hombres se ubican en la parte inferior, lo cual define las funciones de lo masculino y lo femenino dentro del relato. En las alturas (nueva ironía de Heine), el sector femenino representa la distensión, el chusmerío banal, la opulencia y la sensualidad vulgarizada de la materia, como un retroceso de lo espiritual; mientras que en el sector 
masculino, prima la solemnidad, y la represión espiritual: "Mientras en la parte de abajo se leen párrafos de la Ley en el libro de Moisés, arriba la devoción acostumbraba a ser algo más relajada... la devoción hace retrocesos aún mayores: se charla, se hacen grupos, se ríe..." (HEINE, 1995, p. 277).

En este contexto de decadencia generalizada, el personaje femenino de Sara se evade, primero, a través del poder transfigurador de la realidad que tiene la música, al igual que sucedía en Noches Florentinas:

\footnotetext{
A la hermosa Sara le pareció como si las columnas del arca sagrada empezaran a florecer y las maravillosas flores y hojas de los capiteles crecieran más y más, y los sonidos del tiple se transformaron en puros cantos de ruiseñor, y la bóveda de la sinagoga reventara con los poderosos sonidos del bajo, y la alegría de Dios se derramara desde el cielo azul (HEINE, 1995, p. 275).
}

Luego, ante la imposibilidad de evasión, y al escuchar a Rabí Abraham agradeciendo la salvación, cae desmayada, como emblema del desgarro: "su alma se sintió desgarrada por la certeza de que sus amados y parientes habrían sido realmente asesinados, de que su sobrinita estaría muerta" (HEINE, 1995, p. 280).

El relato culmina nuevamente con un personaje que encarna el ideal Saint-simoniano del sensualismo panteísta, al igual que los personajes de Jan Steen y Lorenza en los relatos anteriores. Se trata del caballero español que se opone al espiritualismo del rabino, ya que reúne en su persona al ascetismo judeo-cristiano y al sensualismo de los dioses griegos, dado que prioriza la virtud antes que la belleza, y la satisfacción en vida de los placeres: “¡Sólo mi rodilla y mi lengua rinden homenaje a la Muerte, mi corazón se mantiene fiel a la vida!" (HEINE, 1995, p. 285).

\section{Conclusión}

La escisión establecida por el judeo-cristianismo entre espiritualismo y sensualismo, que se prolonga en la literatura del Romanticismo a partir de sus representaciones etéreas, idealizadas y desapegadas del presente; le permite a Heine utilizar esos mismos motivos para criticarlos, y al hacerlo, criticar todo un estado de cosas de su presente histórico. Tal escisión marca un desgarramiento que se extiende en la representación de los personajes y en la propia estructura narrativa, la cual por momentos parece fragmentaria. Así, el desgarro establecido entre el espíritu y la materia supone un desgarro paralelo entre la dimensión de la realidad prosaica y la dimensión del deseo individual, que en los relatos se traduce en la necesidad de apelar a otro nivel de representación, como lo son el sueño, los recuerdos y la fantasía. Esta dimensión "otra", entra en contraste con la realidad prosaica, en tanto es producto de la 
pérdida de armonía que atraviesa a los individuos; ya que en la dimensión de la realidad, la materia sólo puede existir sensualmente en términos enfermizos, fantasmagóricos o espectrales, como sucede con la mayoría de las representaciones femeninas en los relatos; o de manera sumamente vulgar y corrompida, cuando se la relaciona con el mundo del capitalismo burgués, como sucede en Hamburgo, en Londres y en Frankfurt respectivamente.

Es esta la razón por la cual el desgarramiento que padece el sujeto moderno genera un sector de seres marginados, que son aquellos históricamente asociados por el judeocristianismo patriarcal con lo sensual: las mujeres. Lo femenino en los relatos de Heine asume una representación privilegiada, en tanto alberga una dimensión utópica en términos revolucionarios, porque se opone al sistema espiritual y masculino imperante. La oposición implica un movimiento paralelo de asociación de tales figuras con el orden de representaciones oníricas y fantásticas, lo que les permite vehiculizar un modelo alternativo vinculado a las nuevas necesidades históricas.

Tal antítesis se observa, en el primer relato, a partir de la oposición entre el personaje de la madre del narrador y el del padre; en el segundo relato, se evidencia en el universo de personajes femeninos por oposición al personaje del médico, y finalmente en el relato $E l$ rabino de Bacherach, se evidencia en el personaje de Sara por oposición al rabino y la comunidad judía en general.

Así, los relatos se mueven en la tensión que implica una mirada crítica del pasado y del presente, tanto estético como político, en tanto pretenden ofrecer una resolución ante tal desgarro. La superación resulta para Heine, su ideal de panteísmo sensualista Saintsimoniano, que refleja la síntesis entre el componente de sensualidad irreligiosa, y el componente religioso panteísta, a partir de un más acá terrenal y revolucionario. En los relatos, tal ideal utópico se encuentra representado en los personajes del pintor Jan Steen, el judío español, y el personaje de Lorenza y la música de Paganini. Esto pone en evidencia finalmente, la función crítica y revolucionaria que para Heine asume el arte (al igual que lo femenino), como el ámbito de restitución de la armonía perdida:

\footnotetext{
A pesar de su carácter en apariencia privado e individual, el arte es el lugar al que han ido a refugiarse los valores auténticos de la humanidad, en tiempos en que mantiene una inexpugnable hegemonía el homo economicus. En el presente, la utopía es, para Heine, el sueño - estético- de una cosa que sólo podrá realizarse en un futuro en que el hombre ya no sea el enemigo del hombre (VEDDA, 2008, p.164).
}

\section{Referencias}


ADORNO, Theodor W. (1949). Hacia una revalorización de Heine. Miscelánea II. Madrid: Akal, 2014.

FORTEA, Carlos. Introducción. In: HEINE, Heinrich. Relatos. Barcelona: Altaya, 1995.

HEINE, Heinrich. Libro de los cantares. Prosa escogida. México DF: Porrúa, 1984. . La Escuela Romántica. Buenos Aires: Biblos, 2007. . Relatos. Barcelona: Altaya, 1995.

. Sueños y canciones. Bogotá: El Ancora, 1996.

LARGO, José Ramón Martín. Los escritores y la música. Filomúsica Revista, n. 37, febrero de 2003. Disponible en: <http://www.filomusica.com/filo37/heine2.html $>$. Acceso en 20/05/2017.

LUKACS, Georg. (1935). Realistas alemanes del siglo XIX. Barcelona: Grijalbo, 1970.

VEDDA, Miguel. Heine como narrador. La utopía estética en las Noches Florentinas. In: ROHLAND DE LANGBEHN, R. y VEDDA, Miguel. (Eds.), Anuario Argentino de Germanística III, Buenos Aires: Asociación Argentina de Germanistas, 2008, p. 155-164.

The Heine-Tear: the tension between Spiritualism and Sensualism in three short stories. Abstract: To approach Heine's literature is to enter the world of one of the most controversial authors, and also one of the most conscious intellectuals about the historical crisis of his time. His work suffers the tension between Romanticism and Modern Era, this is why he tried to give a new esthetic answer that contemplated a critical view of everything that was presented as new, as well as of his past cultural heritage. This article tries to analyze Heine's three short stories - De las memorias del señor de Schnabelewopski, published in 1833, Noches Florentinas of 1835, and El rabino de Bacherach published in 1840- which problematize the tension between spiritualism and sensualism, in order to demonstrate that de broken unity presented as a contradiction of elements, characters and spaces, constitute the structural procedure of Heine's literature. Finally, the dichotomy between spiritualism and sensualism stablished by Jewish-christian religion, that continued during Romanticism through its idealized and ahistorical representations, encouraged Heine to use those procedures in order to criticize them, as well as the whole statu quo of his time.

Keywords: German Literature. German Romanticism. The Young Germany. Heinrich Heine. Spiritualism and Sensuality.

Recebido: 09/01/2017

Aceito: $16 / 05 / 2017$

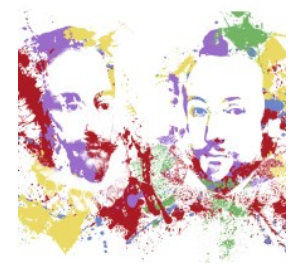

